\title{
PENINGKATAN KETRAMPILAN AKUNTANSI DAN TEKNOLOGI PENGEMASAN PADA USAHA SERBUK JAHE DI DESA GETASPEJATEN, KABUPATEN KUDUS
}

\author{
Aprilia Whetyningtyas ${ }^{*}$, Diah Ayu Susanti ${ }^{2}$ Masruki Kabib ${ }^{3}$ \\ ${ }^{1}$ Prodi Akuntansi, Fakultas Ekonomi dan Bisnis, Universitas Muria Kudus \\ Kampus UMK Gondangmanis Bae, Kabupaten Kudus, 59301 \\ ${ }^{2}$ Prodi Akuntansi, Fakultas Ekonomi dan Bisnis, Universitas Muria Kudus \\ UMK Gondangmanis Bae, Kabupaten Kudus, 59301 \\ ${ }^{3}$ Prodi Tehnik Mesin, Fakultas Tehnik, Universitas Muria Kudus \\ UMK Gondangmanis Bae, Kabupaten Kudus, 59301 \\ "Email: whety.07umk@gmail.com
}

\begin{abstract}
Abstrak.
Penggunaan teknologi tepat guna berupa software akuntansi dan teknologi pengemasan mempunyai peranan penting untuk mencapai keberhasilan usaha, termasuk bagi usaha mikro, kecil dan menengah (UMKM). Permasalahan yang dihadapi mitra yakni manajemen keuangan yang kurang baik dan tidak adanya laporan keuangan yang sesuai standar, mitra juga belum menguasai teknologi pengemasan produk serbuk jahe dalam bentuk kemasan sachet. Tujuan pengabdian pada masyarakat untuk meningkatkan ketrampilan pencatatan akuntansi dengan software akuntansi MYOB (Mind Your Own Bussiness) untuk menghasilkan laporan keuangan secara otomatis, dan memberikan teknologi pengemasan sederhana untuk menghasilkan produk serbuk jahe dalam bentuk kemasan sachet sehingga produk dapat dipasarkan dengan jangkauan pasar yang lebih luas. Metode yang digunakan adalah dengan mengimplementasikan software akuntansi MYOB dalam pencatatan akuntansi dan penyusunan laporan keuangan serta pembuatan mesin pengemas sederhana untuk kemasan sachet produk serbuk jahe. Target luaran yang ingin dicapai dalam kegiatan ini adalah meningkatnya kemampuan mitra dalam melakukan pencatatan keuangan melalui aplikasi software akuntansi MYOB dan memahami manfaatnya serta penggunaan teknologi mesin pengemas serbuk jahe yang menghasilkan produk serbuk jahe dalam kemasan sachet.
\end{abstract}

Kata kunci: jahe, mesin pengemas, software akuntansi

\section{PENDAHULUAN}

Usaha mikro kecil dan menengah adalah usaha ekonomi produktif yang berdiri sendiri, yang dilakukan oleh orang perorangan atau badan usaha, yang bukan merupakan anak perusahaan atau bukan cabang perusahaan yang dimiliki, dikuasai, atau menjadi bagian baik langsung maupun tidak langsung dari usaha menengah atau usaha besar, yang memenuhi kriteria usaha kecil (UU No. 20 Tahun 2008 tentang Usaha Mikro, Kecil dan Menengah). Kudus merupakan daerah industri dan perdagangan, dimana sektor ini mampu menyerap banyak tenaga kerja. Bidang pangan juga ikut memberikan citra industri kota Kudus, seperti jahe. Jahe merupakan bahan pangan alami yang baik untuk menghangatkan dan meningkatkan stamina tubuh manusia. Oleh karena itu, jahe banyak dimanfaatkan untuk berbagai produk olahan seperti minuman serbuk jahe.

Minuman serbuk merupakan produk pangan berbentuk butiran yang mudah larut dalam air. Cara penyajiannya cukup ditambah dengan air dan siap untuk dikonsumsi. Minuman serbuk jahe merupakan jahe yang diekstrasi lalu dikeringkan dan diolah menjadi serbuk. Produk ini disukai oleh masyarakat sebab dapat disajikan secara mudah dan praktis. CV. Karunia Abadi merupakan salah satu industri pengolahan minuman serbuk jahe di Kudus. Perusahaan yang menjadi mitra kegiatan pengabdian ini berlokasi di desa Getaspejaten, kecamatan Jati, kabupaten Kudus. Perusahaan ini berdiri sejak tahun 2013. Bahan baku yang digunakan untuk minuman serbuk jahe berupa jahe emprit dan gula kristal putih.

CV. Karunia Abadi hanya menggunakan jahe emprit/jahe putih yang tidak terlalu pedas. Jahe ini cocok untuk ramuan obat-obatan, atau untuk diekstrak oleoresin dan minyak atsirinya. Beberapa 
supplier jahe emprit yang diterima oleh CV. Karunia Abadi berasal dari Ungaran, Temanggung, Kudus. Dalam membuat minuman serbuk jahe, mitra menggunakan gula kristal putih sebagai bahan pemanis alami tanpa tambahan bahan pemanis buatan. CV. Karunia Abadi dapat memproduksi serbuk jahe sebanyak 2 ton/minggu. Omset penjualan serbuk jahe saat ini sebanyak 7-10 ton per bulan. Penjualan serbuk jahe dilakukan dalam bentuk sak/karung $25 \mathrm{~kg}$ dan hanya dijual kepada sebuah perusahaan besar di Tangerang berdasarkan pesanan. Serbuk jahe yang dijual ke perusahaan besar di Tangerang sudah memenuhi sertifikasi Sukofindo dari Semarang.

Adapun permasalahan yang dihadapi oleh mitra saat ini dalam aspek manajemen usaha yaitu manajemen keuangan yang kurang baik dan tidak adanya laporan keuangan yang sesuai standar. Standar akuntansi keuangan (SAK) merupakan suatu kerangka dalam prosedur pembuatan laporan keuangan agar terjadi keseragaman dalam penyajian laporan keuangan. Pernyataan Standar Akuntansi Keuangan yang berlaku untuk UMKM saat ini adalah SAK-ETAP.

Selama ini laporan keuangan yang dibuat oleh mitra masih sederhana, diharapkan dengan kegiatan pengabdian ini dapat memberikan pelatihan dalam membantu mitra terutama penyusunan laporan keuangan secara terkomputerisasi sehingga laporan keuangan yang dihasilkan menjadi lebih baik. Pencatatan keuangan pada dasarnya merupakan kegiatan akuntansi untuk memberikan pertanggungjawaban atas kegiatan dagang yang dilakukan. Pertanggungjawaban ini sangat penting dalam rangka upaya mengembangkan usaha yang telah dan akan dilakukan serta untuk mengetahui omset yang diperoleh (Hardiningsih dkk, 2016).

Menurut Ikatan Akuntan Indonesia (2009), laporan keuangan adalah catatan informasi keuangan suatu perusahaan pada periode akuntansi yang menggambarkan kinerja perusahaan tersebut. Laporan keuangan akan digunakan oleh perusahaan untuk berbagai macam kebijakan. Informasi yang akan didapatkan dari perusahaan antara lain : (1). Informasi perubahan jumlah modal pemilik; (2) Informasi kinerja keuangan perusahaan; (3). Informasi posisi keuangan perusahaan terkait dengan sumber dana dan jenis penggunaan dana; (4). Informasi pemasukan uang (kas) dan pengeluaran uang (kas).

Sedangkan permasalahan yang dihadapi mitra usaha jahe saat ini dalam aspek produksi yaitu mitra belum menguasai teknologi pengemasan produk serbuk jahe dalam bentuk kemasan sachet. Selama ini mitra menjual serbuk jahe produksinya hanya dalam bentuk karung/sak $25 \mathrm{~kg}$ kepada sebuah perusahaan besar di Tangerang berdasarkan pesanan, hal ini dirasakan kurang efisien karena menjualnya dalam jumlah yang banyak dan dengan harga yang cukup terjangkau di pasar. Mitra juga berkeinginan untuk menjual serbuk jahe dalam bentuk kemasan sachet 25 gram, supaya produk serbuk jahe dapat dipasarkan dengan jangkauan pasar yang lebih luas. Maka diperlukan adanya inovasi untuk dapat bersaing di pasar, sehingga dibutuhkan perbaikan dalam segi kemasan dalam sachet.

Kemasan adalah wadah atau pembungkus yang dapat membantu mencegah atau mengurangi terjadinya kerusakan-kerusakan pada bahan yang dikemas atau dibungkusnya. Kerusakan yang terjadi sering diakibatkan karena pengaruh dari luar (Buckle dkk, 1987). Pengemasan dilakukan untuk mempertahankan mutu dan umur simpan produk selama penyimpanan, memudahkan distribusi, dan memberikan daya tarik pada konsumen, serta dapat meningkatkan nilai jual produk tersebut. Dengan adanya inovasi baru dalam packaging dapat meningkatkan jumlah produksi dan harga jual produk, karena apabila serbuk jahe tersebut dijual dalam bentuk sak/karung dipasaran, banyak konsumen yang kurang tertarik membelinya, karena jumlahnya yang terlalu banyak dan tidak sesuai dengan kebutuhan konsumen. Yang nantinya produksi serbuk jahe dalam bentuk kemasan sachet dapat dijual sendiri melalui pasar retail maupun agen distribusi.

Dalam realisasinya dibutuhkan adanya peralatan pengemasan atau packaging sachet yang otomatis, sehingga menghasilkan produk yang dapat diminati oleh banyak konsumen dan mampu bersaing di pasaran. Sistem penjualan dalam kemasan sachet merupakan salah satu strategi bisnis untuk menarik minat konsumen, diharapkan nantinya dengan inovasi yang lakukan mitra dapat meningkatkan omset penjualan dan keuntungan.

Berdasarkan permasalahan tersebut, maka perlu adanya program pemberdayaan usaha baik dari sisi manajemen usaha maupun produksi. Suhartini (2003) dalam Muttaqin, dkk (2015) menyatakan bahwa strategi yang tepat dan sesuai untuk diterapkan oleh perusahaan dalam upaya mengembangkan usahanya antara lain mempertahankan citra/image perusahaan, mempertahankan dan meningkatkan kualitas produk, meningkatkan jumlah dan jenis produk dengan meningkatkan diversifikasi produk, 
memperluas daerah pemasaran ke pasar baru, memperbaiki jalur distribusi, meningkatkan kegiatan promosi, pengembangan sumber daya manusia, meningkatkan pengendalian mutu, dan menerapkan teknologi yang lebih canggih.

Kegiatan pengabdian masyarakat pada mitra usaha serbuk jahe ini bertujuan untuk (1) memberikan pelatihan dan pendampingan dalam proses pembukuan usaha menggunakan aplikasi software akuntansi MYOB; (2) memperkenalkan dan membuat teknologi pengemasan berupa mesin pengemas serbuk jahe dalam bentuk kemasan sachet sesuai kebutuhan mitra.

Target luaran dari kegiatan pengabdian masyarakat ini bagi mitra usaha serbuk jahe yaitu peningkatan ketrampilan pencatatan akuntansi dan penyusunan laporan keuangan dengan menggunakan software akuntansi MYOB, peningkatan omset penjualan melalui peningkatan teknologi pengemasan produk serbuk jahe dalam bentuk kemasan sachet, serta mendorong peningkatan kesejahteraan mitra usaha serbuk jahe.

\section{METODE}

Metode pendekatan yang dipilih untuk menyelesaikan masalah terkait aspek manajemen usaha dan produksi adalah (1) Persiapan. Dalam tahap ini meliputi kegiatan koordinasi dengan mitra untuk membuat kesepakatan tentang jadwal kegiatan pelatihan dan pendampingan penyusunan laporan keuangan dengan software MYOB, diskusi mengenai jenis-jenis transaksi yang sering terjadi pada usaha mitra, mempersiapkan materi pelatihan dan pendampingan pembuatan laporan keuangan, diskusi mengenai spesifikasi mesin pengemas serbuk jahe yang akan dibuat sesuai kebutuhan mitra. (2) Pelatihan dan pendampingan pencatatan akuntansi serta penyusunan laporan keuangan menggunakan software akuntansi MYOB. Dengan tujuan agar kondisi keuangan mitra tertata dengan baik dan sesuai standar sehingga laporan yang dihasilkan menjadi lebih baik yang bermanfaat dalam pengambilan keputusan bisnis. (3) Pembuatan teknologi pengemasan berupa mesin pengemas sachet untuk hasil produksi serbuk jahe. Mitra membutuhkan mesin pengemas serbuk jahe dalam bentuk kemasan sachet. Dengan menyediakan mesin tersebut, mitra diharapkan dapat mengoperasikan, merawat, meningkatkan jumlah produksi serbuk jahe kemasan sachet sehingga dapat meningkatkan omset penjualan bagi mitra.

\section{HASIL DAN PEMBAHASAN}

Pada tahap ini merupakan pelaksanaan kegiatan pengabdian kepada mitra usaha jahe. Pelaksanaan kegiatan diawali dengan melakukan kunjungan ke usaha mitra, serta berdiskusi dengan mitra terkait pelaksanaan solusi kegiatan pengabdian pada masyarakat. Materi yang dibahas meliputi pembahasan transaksi-transaksi yang terjadi dalam kegiatan operasional usaha mitra untuk dasar dalam pencatatan akuntansi dan penyusunan laporan keuangan dengan software MYOB; kemudian pembahasan mengenai spesifikasi mesin pengemas serbuk jahe yang dibutuhkan mitra. Dalam kegiatan tersebut, mitra usaha jahe sangat mendukung dan berperan aktif dalam memberikan informasi yang dibutuhkan untuk implementasi solusi.

Tahap berikutnya adalah kegiatan pelatihan dan pendampingan tentang cara pengoperasian software akuntansi MYOB untuk mencatat transaksi-transaksi yang terjadi di UMKM Jahe dan menyusun laporan keuangan secara terkomputerisasi. Mitra pengabdian berperan aktif dalam memberikan informasi terkait transaksi/komponen/akun pengeluaran dan penerimaan usaha.

Laporan keuangan merupakan informasi yang dapat digunakan oleh berbagai pengguna kepentingan untuk mengetahui kinerja suatu perusahaan, dan tolak ukur dalam menilai kesehatan suatu perusahaan. Mitra usaha jahe diharapkan mempunyai laporan keuangan untuk menganalisis kinerja keuangan sehingga dapat memberikan informasi tentang posisi keuangan, produktivitas/kinerja, dan arus kas usaha yang bermanfaat dalam pengambilan keputusan ekonomi.

Dengan adanya pencatatan laporan keuangan yang baik, pemilik usaha akan lebih bijak dalam menyalurkan dana yang dimiliki untuk memajukan usahanya tersebut dan menjadi data perhitungan dalam menentukan berapa modal yang harus dikeluarkan dan berapa keuntungan yang akan diperoleh. Laporan keuangan juga menunjukkan apa yang telah dilakukan manajemen (stewardship) atau pertanggungjawaban manajemen atas sumber daya yang dipercayakan kepadanya (SAK ETAP, 2009).

Dengan pelatihan dan pendampingan ini, diharapkan mitra pengabdian mampu melakukan pencatatan keuangan usaha secara tertib dan jelas. Selain itu, mitra dapat mengetahui kondisi 
keuangan usaha yang selama ini mereka jalankan sehingga bermanfaat dalam pengambilan keputusan bisnis.

Tahap berikutnya adalah pembuatan mesin pengemas atau packaging yang otomatis dan sederhana untuk mengemas produk serbuk jahe dalam bentuk kemasan sachet. Kecepatan mesin pengemas untuk produk serbuk jahe yaitu bisa menghasilkan 900 sachet/jam dan massa tiap sachet 25 gram. Kemasan adalah menjadi salah satu yang memiliki peran dalam meningkatkan penjualan, karena salah satu fungsi kemasan adalah sebagai sarana komunikasi dan informasi kepada konsumen melalui label design yang terdapat pada kemasan. Oleh karena itu kemasan yang dibuat dengan menarik akan memberikan pesan dan kesan yang berbeda kepada calon konsumen yang membuat calon konsumen tertarik dengan produk yang dijual tersebut.

Adanya kemasan dapat membantu mencegah/mengurangi kerusakan, melindungi bahan yang ada di dalamnya dari pencemaran serta gangguan fisik seperti gesekan, benturan dan getaran. Dari segi promosi kemasan berfungsi sebagai perangsang atau daya tarik pembeli (Syarief, 1989). Bahan kemasan yang akan digunakan oleh mitra yaitu dari Alumunium Foil. Kemasan Alumunium Foil adalah bahan kemasan berupa lembaran logam aluminum yang padat dan tipis dengan ketebalan $<0.15$ $\mathrm{mm}$. Pada umumnya kemasan ini digunakan untuk produk-produk yang perlu terlindung dari cahaya matahari dan produk bubuk yang mudah menggumpal. Selain itu, kemasan aluminium foil biasa digunakan sebagai pengemas produk kopi, bumbu atau pada produk-produk olahan yang membutuhkan perlindungan khusus untuk dapat menjaga rasa, isi kandungan dan kebersihan dari suatu produk. Sifat-sifat dari alumunium foil memiliki sifat tidak berbau, tidak ada rasa, tidak berbahaya dan hygienis, tidak mudah membuat pertumbuhan bakteri dan jamur. Aluminium foil dapat digunakan untuk mengemas produk buah-buahan dan sayuran, produk daging, ikan dan kerangkerangan, produk susu dan minuman.

Menurut Susanto dan Sucipta (1994), pengemasan bahan pangan harus memperlihatkan lima fungsi utama, yaitu :

a) Harus dapat mempertahankan produk agar bersih dan memberikan perlindungan terhadap kotoran dan pencemaran lainnya.

b) Harus memberi perlindungan pada bahan pangan terhadap kerusakan fisik, air, oksigen, dan sinar.

c) Harus berfungsi secara benar, efisien, dan ekonomis dalam proses pengepakan. Hal ini berarti bahan pengemas harus sudah dirancang untuk siap pakai pada mesin-mesin yang ada.

d) Harus mempunyai suatu tingkat kemudahan untuk dibentuk menurut rancangan, dimana bukan hanya memberikan kemudahan pada konsumen (dalam membuka atau atau menutup kembali kemasan) juga harus mempermudah pada tahap selanjutnya selama pengelolaan di gudang dan selama pengangkutan untuk distribusi.

e) Harus memberi pengenalan, keterangan, dan daya tarik penjualan.

Dengan adanya produk serbuk jahe dalam kemasan sachet 25 gram, mitra menargetkan akan menambah kapasitas produksi serbuk jahe sebanyak 5 ton per bulan. Produk serbuk jahe kemasan sachet ini akan diberi nama "Sari Jahe" dan akan dipasarkan ke distributor wilayah Surabaya. Diharapkan dengan perluasan jangkauan pemasaran, akan meningkatkan omset penjualan dan keuntungan bagi mitra usaha jahe.

\section{KESIMPULAN}

Pelaksanaan kegiatan pengabdian pada masyarakat telah dijalankan dengan baik dan berjalan optimal. Kegiatan pengabdian ini dapat memberikan manfaat bagi mitra usaha jahe dalam keberlanjutan usahanya. Mitra usaha jahe telah mendapatkan ketrampilan dalam pencatatan akuntansi dan mampu menyusun laporan keuangan menggunakan software akuntansi MYOB. Pencatatan keuangan usaha dapat menjadikan mitra lebih bankable sehingga dapat mengakses permodalan dari lembaga keuangan untuk dapat mengembangkan usahanya.

Mitra usaha serbuk jahe dapat menggunakan mesin pengemas serbuk jahe yang menghasilkan kemasan bentuk sachet 25 gram. Mitra dapat meningkatkan kapasitas produksi serbuk jahe untuk dipasarkan sehingga omset penjualan meningkat yang pada akhirnya pendapatan mitra juga meningkat. Dan mitra juga telah mendapat pengetahuan tentang pentingnya kemasan produk sachet untuk menarik minat konsumen karena sesuai kebutuhan dan dapat menjaga kualitas serbuk jahe. 


\section{DAFTAR PUSTAKA}

Buckle, K. A., R. A. Edwards, G. H. Fleet, dan M. Wooton. 1987. Ilmu Pangan. Jakarta: Universitas Indonesia Press.

Hardiningsih P, Oktaviani RM, Sunarto. 2016. Peningkatan Ketrampilan Akuntansi dan Pemasaran Kelompok Olahan Keripik Kabupaten Semarang. ABDIMAS. Vol. 20. No. 2. Desember.

Ikatan Akuntan Indonesia (IAI). 2009. Standar Akuntansi Keuangan Entitas Tanpa Akuntabilitas Publik. Dewan Standar Akuntansi Keuangan, Jakarta.

Muttaqin H, Cahyadin M, Widiyanti E. 2015. Pemberdayaan Usaha Jamu Jahe Instan Di Kota Surakarta Dan Kabupaten Sukoharjo Melalui Teknologi Pengolahan Jahe. Inotek.Vol. 19.No. 2.Agustus.

Standar Akuntansi Keuangan Entitas Tanpa Akuntanbilitas Publik. Mei 2009. Ikatan Akuntan Indonesia.

Susanto, T dan N. Sucipta. 1994. Teknologi Pengemasan Bahan Makanan. Blitar: CV. Family.

Syarief, R. S. 1989. Teknologi Pengemasan Pangan. Laboratorium Rekayasa Proses Pangan. Bogor: PAU Pangan dan Gizi, IPB.

Undang-Undang Republik Indonesia Nomor 20 Tahun 2008 Tentang Usaha Mikro, Kecil, dan Menengah 